\title{
PROCESS MANAGEMENT AND TRENDS IN COMPANY MANAGEMENT
}

\author{
Jerzy WĄCHOL \\ AGH University of Science and Technology, Management Faculty, Kraków, Poland; jurek.wachol@onet.eu, \\ ORCID: 0000-0003-0296-0585
}

Purpose: The aim of the study is to present selected elements of management, vital for the future development (change trends) of enterprises, with respect to the global environment, process management and ecology.

Design/methodology/approach: Statistical data analysed, surveys and research literature.

Findings: There are some change trends in the management of enterprises of the future, modern technologies and good management of innovations that will be of importance here, as well as the growing significance of ecology and sustainable development, together with waste recycling and searching for alternative and new energy sources. Process management, in contrast, may be on a similar level of assessment in the future as it is at present.

Research limitations/implications: Survey small research, unrepresentative of the SME sector in the Lesser Poland Voivodeship. Pilot case studies.

Practical implications: For the good development of enterprises of the future, innovations in a new perspective are of great significance. The development of networks of all kinds will also have a large impact on management in the global future with the use of digital platforms, but already global according to the fourth industrial revolution. Nevertheless, when selecting technologies, forms, concepts, methods and management techniques, all their advantages and disadvantages must be considered.

Social implications: Although the ecological approach is not the most crucial for the management and employees of companies, it is nonetheless growing according to evaluations. Ecology and innovation in governance must be taken into account for the benefit of societies.

Originality/value: Own small survey research, pilot studies and own analysed references. On the basis of the analysed economic and social statistics, own observation and research, there are selected aspects of the development enterprise, modern methods of management and in the global environment, having regard to the ecology and risk. Herein are conclusions on the development of changes in organisations and the development of the management process.

Keywords: management process, management methods, sustainable development, environment of enterprises, corporate governance, globalisation.

Category of the paper: Case study, literature review. 


\section{Introduction}

The world economy is developing in an uneven way and is at risk of successive economic crises and slowdowns, which are already occurring sequentially in many countries. Many economic, technological and social elements can quickly move from one country to another using modern technologies and management methods. All this depends on the given country, political and legal aspects and modern information technologies, transport, goods exchange and the possibilities of enterprises and large corporations that want or do not want to invest in a particular area.

As part of the modern global economy, in order to increase the competitiveness of enterprises, it is crucial to seek for and apply more effective forms of organisation, management concepts and management elements.

The development of enterprises is dependent on the local environment (closer, further and global in a given country), region of the world, as well as on the investment risk assessments of international rating agencies. Furthermore, there are also legal, ecological and sustainable development elements.

On the other hand, the spread of certain beneficial occurrences are currently observed much faster from one country to another than in the past, not after a few or several dozen years, months, weeks, but almost instantly.

Despite the increase in GDP dynamics, which may be a certain measure of development (not even taking into account ecology and the so-called well-being, health and life of people), the level of debt of economies is very high (e.g. in the USA), which may be alarming for the future. However, hopes for a better future and development of enterprises are raised by innovations, new technologies, modern management concepts and process management, including ecology and sustainable development.

The rapidly evolving technological and socio-political changes in the world at the turn of the 20th and 21 st century have caused shifts in the functioning of enterprises, both small and large. Even a small enterprise has to face global competition within its environment and can also sell its products on the global market provided there are no economic restrictions and limitations. The flow of economic and technological information can also be very fast through computer networks.

The aim of the study is to present selected elements of management, vital for the future development (change trends) of enterprises, with respect to the global environment, process management and ecology. Through statistical data, own surveys and research literature, certain conclusions are presented regarding the development of future enterprises in a globalised environment. 


\section{The global environment as a factor of change in organisation and management concepts and global economic change in the 21 st century}

Changes in the global economy necessitate changes in the market and in enterprises, which have to search for new technologies and modern management methods in order to be successful. Development is usually described as a change, either positive or negative.

However, the global economy is experiencing recurrent crises. Crises and economic slowdowns, in most cases, impede the positive development of enterprises, or they are shut down. Consequently, investors' optimism is weakening, consumers' willingness to buy is decreasing, and the economy is shrinking, as is the GDP growth rate in a given country.

In the current 21 st century, major economic problems, economic slowdowns and crises have already occurred sequentially in many countries, and more may occur in the next decade. Despite these negative trends, many countries and companies have effectively resisted the crisis of previous years using modern technologies, management concepts and process management. However, China's important global and large economy has continued to grow relatively steadily, although the GDP growth rate here has also decreased to around $6 \%$. China now comes first in terms of the value of GDP (real) in billion dollars (US World Factbook CIA, 2018), ahead of the EU and the US. In terms of the value of China's GDP due to the exchange rate, this is the third position in the world, after the EU and the US. Nevertheless, the Chinese economy continues to slow down, as does the German economy.

The economic future of the world most likely depends on Asia, where the majority of the world's population lives. China's economy may be particularly crucial here, where, for some 20 years or so, there has been significant economic growth even during economic slowdowns and crises in the world. Poland, in turn, has a GDP growth rate of about 4\%, but this does not have a noticeable impact on the standard of living of ordinary people, as salaries in Poland are relatively low compared to the EU. Perhaps it attracts investors because of the cheap labour force, but on the other hand, the lower purchasing power of relatively low paid employees in Poland is not favourable to generating greater demand for the manufacturing output carried out in Poland. What deserves attention here are foreign currency and gold reserves. The biggest reserves are obviously in China with over $\$ 3$ trillion. Whereas in the USA, only about $\$ 117$ billion, and in Poland, as much as $\$ 115$ billion (World Factbook CIA USA, 2018) has been observed for many years. Foreign currency and gold reserves are by far the largest in China, which may also impact the global dollar exchange rate. The cheaper dollar and euro theoretically provide a greater opportunity to export, provided that the exported products do not require a significant amount of foreign exchange in enterprises. However, the US economy is still strong and solvable. 
Decreasing or negative GDP dynamics mean a shrinking economy, fewer opportunities for the development of businesses or even bankruptcy and an outflow of investors from given countries and regions of the world. However, it also results in the search for alternative activities, positive development through innovation, modern technologies and management methods or process management to survive in a competitive market.

By the development of an organisation, one usually means all kinds of positive changes. However, there must be an adequate development proportion for the individual elements of the organisation (social, ecological and economic). From the theoretical point of view and management science, each organisation (enterprise) has a goal, human resources, material and technical resources and organisational structure and functions in a given environment (Peszko, 2002). This development may take place following the so-called "staircase", when the stabilisation period is followed by another development, or at the end, there is a decline and collapse of the organisation (Griffin, 2017). However, other organisations and new enterprises may be established in place of the old organisation or enterprise. The enterprise or the organisation also has its values, its culture and identity. These elements may change, evolve or degrade.

Political and economic friction between the US, the EU, China and other major Asian countries escalated between 2017-2018 and 2019. Some of the economic agreements have been reduced or terminated by the US, other agreements, such as CETA (EU-Canada) or the new USMCA (US, Mexico, Canada), are coming into effect.

Unfortunately, EU funding programmes for businesses and regions (including Poland) may decrease. The EU-leading German economy is beginning to record a slowdown and unfavourable production data. It would be more appropriate to support competitive companies so that they can develop and invest in the EU's less developed areas, which would only provide a greater chance for the competitiveness of the entire EU. The problems of EU integration and differences in countries were always there (Zombirt, 2011), but it seems that, between 2015 and 2018, they became much more evident and intensified through large immigration waves, the projected Brexit, economic problems and political changes in the EU.

Nowadays, in order to achieve success in organisations, it is imperative to apply the so-called modern management concepts and techniques (Brilman, 2002), which are properly adapted to a given situation, within a situational approach, e.g. benchmarking, reengineering, outsourcing, lean management and lean manufacturing, franchising, learning organisation, TQM, kaizen, network enterprise, virtual organisation, IT, computerisation, computer networks, process automation, computer simulations, artificial intelligence, research concepts in business and management (Easterby-Smith et al., 2012; Myers, 2013), statistical and financial methods (Kapferer, 2012; McNeil et al., 2015) and, certainly, process management (Kunasz, 2010). 


\section{Suitability of process management for enterprise development, survey research results}

Process management is defined as the systematised application of relevant concepts, methods and tools of influence at the stages of identification, modelling, controlling, implementation and improvement of processes. Such application is carried out in accordance with the strategic plan, covering the entire organisation in terms of financial, social, IT and knowledge. The process approach is based on information technology, adaptation to changes in the environment and customers and their needs, which are at the beginning and end of the process - as results from many analyses and studies (Bitkowska, 2013; Nadolna, Skowronek-Mielczarek, 2014; Gregorczyk, Ogonek, 2007; Kalinowski, 2015; Harmon, Wolf, 2014; and others). The advantages of process management outweigh the disadvantages (Wąchol, 2018).

The results of these studies confirm the hypothesis that there is a relationship between the degree of implementation of the process approach and the assessment of benefits for the enterprise, especially in terms of: systematising and organising the company's structure, improving the effectiveness and efficiency of processes, creating a good image of the company, improving cooperation with customers, making employees aware of the organisation's objectives, streamlining external communication, normalising work standards and increasing trust in the company by external entities. To a lesser extent, the benefits are confirmed in terms of increasing the company's profits, eliminating errors, improving the timeliness of provided services and shortening the time of process execution, despite usually higher costs at the beginning. Moreover, due to the process approach, it is possible to make the organisation more transparent and to aggregate other modern management concepts. The quality of products and cooperation between the client and the company in shaping common goals and values is also improved.

Survey research (unrepresentative) among 40 employees of the SME sector in the Lesser Poland Voivodeship confirms the significance and usefulness of process management and its application as compared to other elements in management, which is illustrated in Table 1.

The usefulness of process management has been relatively well assessed, and the weighted average score is 3.875 on a scale of 1-5, position No. 8 in the table (21 answers out of 4 and 8 answers out of 5 , i.e. a total of about $72.5 \%$ of all 40 respondents). It is worse with the use of process management (26 "yes" answers - 65\%, and 14 "no" answers - 35\%). The first places were taken by marketing, financial management, as well as profit and company value. On the other hand, ecology, virtual organisation, typically disliked by employees, restructuring and benchmarking - one of the last places, at least due to the weighted average rating. This is not particularly surprising, because similar trends, e.g. due to finance and ecology, were also found in other studies. Process management is in the middle of the table in this 
comparison. Ecology has a weighted average rating of 3.525 , item 11 out of 14 , with $50 \%$ application according to these surveys.

Table 1.

Usefulness and application of currently selected elements in management

\begin{tabular}{|c|c|c|c|c|c|c|c|c|c|}
\hline \multirow[t]{2}{*}{ No. } & \multirow[t]{2}{*}{$\begin{array}{l}\text { Number of answers/ } \\
\text { management element }\end{array}$} & \multicolumn{5}{|c|}{$\begin{array}{l}\text { Number of ratings on a } \\
\text { scale of } 1-5 \text { for the } \\
\text { usefulness of selected } \\
\text { elements in management, } \\
\text { (1 min, } 5 \text { max })\end{array}$} & \multirow{2}{*}{$\begin{array}{c}\text { Weighted average } \\
\text { assessment of the } \\
\text { usefulness of } \\
\text { selected elements in } \\
\text { management }\end{array}$} & \multicolumn{2}{|c|}{$\begin{array}{l}\text { Application of these } \\
\text { elements in the } \\
\text { organisation where } \\
\text { the respondents work } \\
\text { (in their opinion) }\end{array}$} \\
\hline & & 1 & 2 & 3 & 4 & 5 & & Yes & No \\
\hline 1 & Marketing & 0 & 0 & 4 & 15 & 21 & 4.425 & 33 & 7 \\
\hline 2 & Financial management & 0 & 3 & 2 & 15 & 20 & 4.300 & 31 & 9 \\
\hline 3 & Profit and company value & 0 & 1 & 3 & 20 & 16 & 4.275 & 35 & 5 \\
\hline 4 & Business plan & 1 & 3 & 4 & 13 & 19 & 4.150 & 35 & 5 \\
\hline 5 & HR & 1 & 4 & 7 & 8 & 20 & 4.050 & 31 & 9 \\
\hline 6 & IT & 1 & 1 & 11 & 12 & 15 & 3.975 & 32 & 8 \\
\hline 7 & Knowledge management & 2 & 0 & 6 & 24 & 8 & 3.900 & 28 & 12 \\
\hline 8 & Process management & 0 & 2 & 9 & 21 & 8 & 3.875 & 26 & 14 \\
\hline 9 & Outsourcing & 2 & 0 & 12 & 21 & 5 & 3.675 & 30 & 10 \\
\hline 10 & Lean Management & 1 & 1 & 14 & 18 & 6 & 3.675 & 21 & 19 \\
\hline 11 & Ecology & 2 & 4 & 11 & 17 & 6 & 3.525 & 20 & 20 \\
\hline 12 & Virtual organisation & 2 & 4 & 13 & 14 & 7 & 3.500 & 22 & 18 \\
\hline 13 & Restructuring & 0 & 4 & 17 & 16 & 3 & 3.450 & 30 & 10 \\
\hline 14 & Benchmarking & 1 & 7 & 13 & 18 & 1 & 3.275 & 18 & 22 \\
\hline
\end{tabular}

Source: own elaboration based on survey research conducted in the Lesser Poland Voivodeship, January 2019.

\section{Change trends in enterprises and the sustainable development of enterprises in the 21 st century}

Despite the fact that ecology is still not best evaluated in empirical research by the employees of companies and organisations, its significance is growing, and it has to be applied more and more often due to legal conditions, which slowly becomes a mandatory change trend. For companies in this sphere, sustainable development is very important, taking into account ecological, social and economic values. This development applies mainly to longer periods of time (Rogall, 2010) and cannot be predatory. This is because it is about meeting the needs not only of present, but also of future generations, as well as taking care of the natural environment. 
Sustainable development is also defined as a way of exploiting natural resources, executing investments and creating technologies that will increase the economic, natural and social basis for satisfying the needs of present and future generations (Piontek, 2002). The value of socially responsible sustainable enterprise is understood in a broader perspective, not only economic and financial, but also ecological and social (Kryński et al., 2013), which must be used harmoniously in a given environment and conditions. This is primarily in the long-term interest of the organisation, enterprises and business, and not just its environment and society (Bluszcz, 2017).

A sustainable enterprise should take into account economic, social and environmental values.

However, not everyone appreciates ecological values in the pursuit of profit or the satisfaction of social needs.

Table 2 presents the subsequent survey research of 50 employees in the Lesser Poland Voivodeship, presenting selected elements of management, which, in the opinion of the respondents, will have the greatest application in enterprises in the future of the 21 st century.

Table 2.

Selected elements of management that will be essential for the enterprises of the future

\begin{tabular}{|c|c|c|c|c|c|c|c|}
\hline \multirow[t]{2}{*}{ No. } & \multirow[t]{2}{*}{$\begin{array}{c}\text { Number of answers/ } \\
\text { element }\end{array}$} & \multicolumn{5}{|c|}{$\begin{array}{l}\text { Percentage of responses on a scale of } \\
1-5 \text { for usefulness of selected } \\
\text { management elements }(1 \mathrm{~min}, 5 \mathrm{max})\end{array}$} & \multirow{2}{*}{$\begin{array}{c}\text { Weighted average assessment } \\
\text { of the usefulness of selected } \\
\text { elements in management } \\
(1 \mathrm{~min}, 5 \text { max })\end{array}$} \\
\hline & & 1 & 2 & 3 & 4 & 5 & \\
\hline 1 & New technologies & 2 & 4 & 6 & 24 & 64 & 4.90 \\
\hline 2 & Financial management & 0 & 2 & 4 & 46 & 48 & 4.40 \\
\hline 3 & Quality management & 2 & 2 & 10 & 38 & 48 & 4.28 \\
\hline 4 & Innovation management & 4 & 6 & 8 & 40 & 42 & 4.10 \\
\hline 5 & Profit and company value & 0 & 2 & 22 & 46 & 50 & 4.04 \\
\hline 6 & Marketing & 2 & 10 & 18 & 26 & 44 & 4.00 \\
\hline 7 & Waste recycling & 6 & 8 & 27 & 22 & 42 & 3.86 \\
\hline 8 & Knowledge management & 2 & 6 & 32 & 28 & 32 & 3.82 \\
\hline 9 & $\begin{array}{l}\text { Searching for alternative } \\
\text { and new energy sources }\end{array}$ & 8 & 10 & 22 & 14 & 46 & 3.80 \\
\hline 10 & Ecology & 4 & 12 & 26 & 18 & 40 & 3.78 \\
\hline 11 & Process management & 6 & 8 & 24 & 28 & 34 & 3.76 \\
\hline 12 & Business plan & 4 & 12 & 24 & 32 & 28 & 3.68 \\
\hline 13 & HR & 6 & 8 & 30 & 34 & 22 & 3.58 \\
\hline 14 & Lean Management & 4 & 8 & 40 & 24 & 24 & 3.56 \\
\hline
\end{tabular}


Cont. table 2.

\begin{tabular}{|l|c|c|c|c|c|c|c|}
\hline 15 & Benchmarking & 4 & 12 & 34 & 38 & 12 & 3.42 \\
\hline 16 & Outsourcing & 4 & 16 & 38 & 30 & 12 & 3.30 \\
\hline 17 & Virtual organisation & 14 & 12 & 28 & 26 & 20 & 3.26 \\
\hline 18 & Restructuring & 8 & 26 & 42 & 14 & 10 & 2.92 \\
\hline
\end{tabular}

Source: own elaboration based on survey research conducted in the Lesser Poland Voivodeship, January 2019.

In the enterprises of the future, the most crucial may be modern technologies (average score 4.90), financial management (4.40) and quality management (4.28). Innovation management (4.10), profit and company value (4.04), marketing (4.00), waste recycling (3.86), knowledge management (3.82), searching for alternative and new energy sources (3.80) and ecology (3.78), which has improved its score compared to Table 1 (3.52). Meanwhile, process management is almost unchanged, with an average score of 3.76 for enterprises of the future according to the respondents.

\section{Conclusions}

There are some change trends in the management of enterprises of the future, and modern technologies and good management of innovations will be of importance here, as well as the growing significance of ecology and sustainable development, together with waste recycling and searching for alternative and new energy sources. Process management, in contrast, may be on a similar level of assessment in the future as it is at present.

Traditionally and frequently used functional structures for both small and large organisations, including global ones, should evolve within the trend of changes to the process structure, encompassing not only functions according to the precursors of scientific management, but also contemporary processes in the organisation and modern management methods and techniques. Therefore, there may be greater flexibility and effectiveness of management, even in the regional and global economy. As research shows, process management has already found its established position in the trends of changes in contemporary organisations. It has allowed one to increase the effectiveness and flexibility of enterprises and has drawn attention to the necessity of a new approach to economic processes on the global market.

Some of the advantages of process orientation include: possible reduction of operating costs, increased efficiency, effectiveness, better description of the organisation's operation, increased flexibility of operation, focus on the customers and their needs, increased control of changes, increased competitiveness of the company, better utilisation of resources, ensuring the possibility of managing external relations, providing a comprehensive business model, reducing 
the error rate, aggregation of other management concepts, etc. The disadvantages of process orientation, however, include problems with its implementation and relatively high costs of initial changes. It is more complicated, yet more transparent, after proper implementation and application.

For the good development of enterprises of the future, innovations in the new perspective are of great significance (Kraśnicka, 2018). The development of networks of all kinds will also have a large impact on management in the global future with the use of digital platforms, but already global according to the fourth industrial revolution (Schwab, 2018; Hammer, 2014; Brocke, Rosemann, 2010). Nevertheless, when selecting technologies, forms, concepts, methods and management techniques, all their advantages and disadvantages must be considered (Harrington, 1991). The situational approach in the given future environment will also be relevant here, as well as the wise utilisation of the knowledge and expertise of the governing bodies. Organisations of the future will probably follow the needs of humanity and technological and material changes, using modern management methods and techniques (Szymańska, 2015). The development of an organisation (company) should also be sustainable, considering not only economic, but also social and ecological values. However, large supranational corporations that bring a significant percentage of GDP to a given country, having substantial resources and assets, must be taken under the control and institutional regulations of the state and citizens. This necessitates in-depth research in the future, including process management in Poland and worldwide.

The world economy is changing, pulsating positively during business prosperity, but also negatively during downturns and crises. However, the trend is now more oriented towards a slowdown, and GDP growth continues, but is slower and is threatened by further crises and economic downturns, as well as depletion of natural resources. This is probably because good modern technologies and modern management methods are applied, substitutes are used, and there is a growing focus on waste recycling and renewable energy sources (solar, wind, hydro, geothermal, etc.). Although the ecological approach is not the most crucial for the management and employees of companies, nonetheless, it is growing according to evaluations. Regulations in the law may lead to additional costs or revenues related to ecology, which entrepreneurs, managers and employees must perceive as financial incentives - one of the most essential for them now and in the future. 


\section{References}

1. Bitkowska, A. (2013). Zarządzanie procesowe we współczesnych organizacjach. Warszawa: Difin.

2. Bluszcz, A. (2017). Metody oceny poziomu zrównoważonego rozwoju Polska na tle Unii Europejskiej. Zeszyty Naukowe Politechniki Ślaskiej, Organizacja i Zarządzanie, 118, Zabrze: Politechnika Śląska.

3. Brilman, J. (2002). Nowoczesne koncepcje i metody zarządzania. Warszawa: PWE.

4. Brocke, J., Rosemann, M. (2010). Handbook on Business Process Management, 1. Berlin: Springer.

5. Easterby-Smith, M., Thorpe, R., Jackson, P. (2012). Management research. London: SAGE Publications.

6. Gregorczyk, S., Ogonek, K. (2007). Uwarunkowania strategiczne zarządzania procesowego. Studia i Prace Kolegium Zarządzania i Finansów, Zeszyt Naukowy, 82. Warszawa: SGH.

7. Griffin, R.W. (2017). Podstawy zarządania organizacjami. Warszawa: PWN.

8. Hammer, M. (2014). What is Business Process Management? Berlin: Springer.

9. Harmon, P., Wolf, C. (2014). The State of Business Process Management 2014. A BP Trends Report, http://www.bptrends.com/bpt/wp-content/uploads/BPTrends-Stateof-BPM-Survey-Report. Pdf, 15.11.2017.

10. Harrington, H.J. (1991). Business Process Improvement. The Breakthrough Strategy for Total Quality, Productivity and Competitiveness. New York: Mc Grraw-Hill.

11. Kalinowski, B. (2015). Wpływ dojrzałości procesowej na efektywność organizacji. Marketing i Rynek, 5, 1030-1035. Warszawa: PWE.

12. Kapferer, J.N. (2012). The new strategic brand management advanced insights and strategic thinking. London: Kogan Page.

13. Kraśnicka, T. (2018). Innowacje w zarządzaniu, nowe ujęcie. Warszawa: C.H. Beck.

14. Kryński, A., Matthias, M., Caekelbergh, A.F. (2013). Zintegrowane zarzadzanie środowiskiem. Warszawa: Wolters Kluwer Polska S.A.

15. Kunasz, M. (2010). Praktyczne aspekty zarzadzania procesami. Szczecin: Economicus.

16. McNeil, A.J., Frey, R., Embrechts, P. (2015). Quantitative risk management, concepts, techniques and tools. New Jersey: Princeton University Press.

17. Myers, M.D. (2013). Quantitative Research in Business \& Management. London: SAGE Publication.

18. Nadolna, M., Skowronek-Mielczarek, A. (2014). Zarzadzanie procesami, a nowoczesne przedsiębiorstwa medialne. Warszawa: CeDeWu.

19. Peszko, A. (2002). Podstawy zarządzania organizacjami. Kraków: Wydawnictwo AGH. 
20. Piontek, B. (2002). Koncepcja rozwoju zrównoważonego i trwałego Polski. Warszawa: PWN.

21. Poskrobko, B., Poskrobko, T. (2012). Zarzadzanie środowiskiem w Polsce. Warszawa: PWE.

22. Rogall, H. (2010). Ekonomia zrównoważonego rozwoju, teoria i praktyka. Poznań: Wydawnictwo Zysk.

23. Schwab, K. (2018). Czwarta rewolucja przemysłowa. Łódź: Studio Emka.

24. Szymańska, K. (2015). Kompendium metod i technik zarządzania. Warszawa: Wolters Kluwer.

25. Toczyski, W. (2004). Monitoring rozwoju zrównoważonego i trwałego. Gdańsk: Wyd. UG.

26. Wąchol, J. (2017). Zarządzanie procesowe w gospodarce globalnej, a inne elementy zarządzania. In: P. Zwiech (ed.), Zarządzanie procesowe w studiach przypadków. Seria „Zarzadzanie procesami w teorii i praktyce”, 8. Szczecin: Uniwersytet Szczeciński.

27. Wąchol, J. (2018). Zarządzanie procesowe, a rozwój przedsiębiorstw w warunkach globalizacji. In: M. Kunasz (ed.), Orientacja procesowa w zastosowaniach. Seria „Zarzadzanie procesami w teorii i praktyce”, 10. Szczecin: Uniwersytet Szczeciński, Wydział Zarządzania.

28. World Factbook CIA, USA. ww.cia.gov, 02.2018.

29. Zombirt, J. (2011). Mechanizmy rynku wewnętrznego Unii Europejskiej. Warszawa: Difin. 